\title{
HAK KONSTITUSIONAL ATAS AIR PASCA DIHAPUSNYA UNDANG UNDANG NOMOR 7 TAHUN 2004 TENTANG SUMBER DAYA AIR OLEH MAHKAMAH KONSTITUSI
}

\author{
NOVA YARSINA \\ Sekolah Tinggi Ilmu Hukum Putri Maharaja Payakumbuh \\ novayarsina@yahoo.com
}

\begin{abstract}
The purpose of this study is to examine human rights over water after the abolition of Law Number 7 of 2004 concerning Water Resources by the Constitutional Court. The research method used is normative juridical. Later there was an opinion that if the state was unable to guarantee the fulfillment of human rights over water, then the water supply was carried out by a third party. The state must regulate the appropriateness of control over water sources, affordability of prices, guarantees for water health. For the realization of these things, a system of regulation must be made. An independent regulatory body can also be formed, public participation, and sanctions against violations. In essence, every regulation issued by the local government related to water use actually makes water as "Economic goods". Commercialization and privatization of water services is not an illegal thing as long as it can improve clean water services so that public access to water also increases. Local governments should be able to understand that commercialization of water resources by setting drinking water tariffs that exceed the capacity and reasonableness of the community actually results in reduced community access to water resources, especially clean water and drinking water. The poor and marginalized are the most vulnerable groups to the failure to fulfill the right to water by the State. To see the extent to which the fulfillment of the right to water by the state apart from the perspective of the executive authority, it is necessary to look at court decisions that can reflect the fulfillment of the right to water especially after the abolition of Law Number 7 of 2004 concerning Water Resources by the Constitutional Court and return to Law Number 11 of 1974 concerning Irrigation.
\end{abstract}

Keywords: Human rights, Water, Constitutional Court.

Abstrak: Tujuan penelitian ini adalah meneliti hak asasi manusia atas air pasca dihapusnya Undang-undang Nomor 7 Tahun 2004 tentang Sumber Daya Air oleh Mahkamah Konstitusi. Metode penelitin yang digunakan adalah yuridis normatif. Belakangan timbul pendapat bahwa bila negara tidak mampu menjamin pemenuhan hak-hak asasi manusia atas air, maka penyediaan air dilakukan oleh pihak ketiga. Negara harus melakukan pengaturan terhadap kepatutan penguasaan terhadap sumber air, keterjangkauan harga, jaminan terhadap kesehatan air. Demi terwujudnya hal-hal tersebut, suatu sistem pengaturan harus dibuat. Dapat pula dibentuk suatu badan pengawas independen, partisipasi publik, dan sanksi terhadap pelanggaran. Pada intinya, setiap regulasi yang dikeluarkan pemerintah daerah terkait pemanfaatan air justru menjadikan air sebagai "Economic goods". Komersialisasi dan privatisasi pelayanan air bukanlah menjadi suatu barang yang haram sepanjang hal tersebut dapat meningkatkan pelayanan air bersih sehingga meningkat pula akses masyarakat terhadap air. Seharusnya pemerintah daerah dapat memahami bahwa komersialisasi sumber daya air dengan menetapkan tarif air minum yang melebihi batas kemampuan

136 Lembaga Penelitian dan Penerbitan Hasil Penelitian Ensiklopedia $\quad$ E-ISSN: 2657-0300

P-ISSN: 2657-0319 
dan kewajaran masyarakat justru mengakibatkan berkurangnya akses masyarakat terhadap sumber daya air, khususnya air bersih dan air minum. Masyarakat miskin dan marginal menjadi kelompok masyarakat yang paling rentan terhadap gagalnya pemenuhan hak atas air oleh Negara. Untuk melihat sejauh mana pemenuhan hak atas air oleh negara selain dari sudut pandang otoritas eksekutif, maka perlu dilihat putusan-putusan pengadilan yang dapat mencerminkan pemenuhan hak atas air terutama pasca dihapusnya Undang Undang Nomor 7 Tahun 2004 Tentang Sumber Daya Air Oleh Mahkamah Konstitusional dan kembali kepada Undang-Undang Nomor 11 Tahun 1974 tentang Pengairan.

Kata Kunci: Hak asasi manusia, Air, Mahkamah Konstitusi.

\section{A. Pendahuluan}

Negara Indonesia memiliki potensi sumber daya yang sangat melimpah dan tidak akan pernah habis serta akan tetap ada sepanjang usia alam itu sendiri, yaitu: manusia, sinar matahari, tanah, hutan, dan laut. Sebagai modal dasar pembangunan nasional, sumber daya alam tentunya harus dimanfaatkan dengan sebaik-baiknya agar dapat mensejahterakan seluruh penduduk Indonesia. Pemanfaatan sumber daya alam juga harus mendukung prinsip pembangunan berkelanjutan, yakni: pembangunan yang dilakukan untuk dapat memenuhi kebutuhan pada masa sekarang, tanpa mengurangi kemampuan generasi yang akan datang untuk dapat memenuhi kebutuhannya

Pasal 33 ayat (3) Undang-undang Dasar 1945 menyatakan:“Bumi dan air dan kekayaan alam yang terkandung di dalamnya dikuasai oleh Negara dan dipergunakan untuk sebesar-besarnya kemakmuran rakyat.' Menurut ketentuan Pasal 33 ayat (3) tersebut, negara bukanlah pemilik tetapi undang-undang dasar hanya memberikan hak penguasaan kepada negara untuk mengelola sesuai dengan tujuan yang telah digariskan oleh UUD 1945 sendiri, yaitu "dipergunakan untuk sebesar-besarnya kemakmuran rakyat." Jadi kedudukan Negara dalam hal ini adalah wali amanat (trustee) dari kekayaan alam berupa air, antara lain, yang dianugerahkan Tuhan kepada bangsa Indonesia. Dengan demikian, UUD 1945 mengadopsi prinsip air sebagai barang publik (Hamid Chal.id, 2009).

Tetapi, permasalahan yang sering kali muncul menyangkut Pasal 33 UndangUndang Dasar 1945, yang perlu mendapat perhatian, ialah tentang aturan pelaksanaannya yang lahir dalam bentuk undang-undang, yaitu tentang bagaimana peranan negara dalam penguasaan sumber daya alam (ekonomi) yang ada. Hak negara dalam menguasai sumber daya alam dijabarkan lebih jauh dalam beberapa undangundang yang mengatur sektor-sektor khusus yang memberi kewenangan luas bagi negara untuk mengatur dan menyelenggarakan penggunaan, persediaan dan pemeliharaan sumber daya alam serta mengatur hubungan hukumnya. Prinsip ini tertuang dalam: 1) UU Nomor 5 Tahun 1960 tentang Pokok-pokok Agraria; 2) UU Nomor 11 Tahun 1967 tentang Pokok-pokok Pertambangan; 3) UU Nomor 1 Tahun 1973 tentang Landasan kontinen; 4) UU Nomor 13 Tahun 1980 tentang Jalan; 5) UU Nomor 4 Tahun 1982 tentang Ketentuan-ketentuan Pokok Pengelolaan Lingkungan Hidup; 6) UU Nomor 20 Tahun 1989 tentang Ketentuan-ketentuan Pokok Pertahanan Keamanan; 7) UU Nomor 23 Tahun 1997 tentang Pengelolaan Lingkungan Hidup; 8) UU Nomor 5 Tahun 1999 tentang Larangan Praktek Monopoli dan Persaingan Usaha Tidak Sehat; 9) UU Nomor 41 Tahun 1999 tentang Pokok-pokok Kehutanan; 10) UU Nomor 22 Tahun 2001 tentang Minyak dan Gas Bumi; 11) UU Nomor 20 Tahun 2002 tentang Ketenagalistrikan; 12) UU Nomor 7 Tahun 2004 tentang Sumber Daya Air; 13) UU Nomor 18 Tahun 2004 tentang Perkebunan; 14) UU Nomor 11 Tahun 2005 E-ISSN: 2657-0300 Lembaga Penelitian dan Penerbitan Hasil Penelitian Ensiklopedia $\quad 137$ P-ISSN: 2657-0319 
tentang Pengesahan International Covenant On Economic, Social, And Cultural Rights (Kovenan Internasional Hak-hak Ekonomi, Sosial, dan Budaya); 15) Undang-undang No. 32 Tahun 2009 tentang Perlindungan dan Pengelolaan Lingkungan Hidup.

Kini banyak daerah mengalami darurat air akibat kemarau panjang, termasuk kondisi waduk beberapa waduk utama. Dari 16 waduk utama Indonesia, sebagian mengalami deficit pada elevasi seperti waduk Sermo di Jawa Timur dengan penurunan dari 18 juta $\mathrm{m}^{3}$ menjadi sekitar 14 juta $\mathrm{m}^{3}$ dan waduk Keuliling di Sulawesi Selatan memiliki kondisi yang sama, belum lagi daerah-daerah tandus seperti di Nusa Tengara Barat dan Nusa Tenggara Timur. Penyebab utama bukan sekedar siklus alam,melainkan juga kerakusan manusia membabat hutan yang menyebabkan daya resap air kedalam tanah diarea hutan semakin mengecil.

Padahal secara potensial kita memiliki kekayaan sumber daya air yang amat besar. Hingga 2013 kita memiliki sekitar 18 wilayah sungai, yakni kesatuan wilayah pengelolaan sumber daya air dan 700 lebih daerah aliran sungai (DAS) yakni wilayah daratan yang meruapakan satu kesatuan dengan sungai dan anak sungai. Selain itu kita juga masih memiliki 1.458 danau yang dijadikan situ(untuk air baku dan irigasi) dengan kapasitas tampung antara 7 juta dan 600 juta $\mathrm{m}^{3}$. Namun diakui banyak danau/situ yang harus direvitalisasi karena dalam kondisi kritis akibat ulah manusia, seperti Danau Toba, Maninjau, Singkarak, Kerinci, Batur, Poso, dan Sentani (Kementerian Pekerjaan Umum Republik Indonesia, 2013).

Atas dasar hal diatas Pimpinan Pusat Muhammadiyah, Solidaritas Juru Parkir, Pedagang Kaki Lima, dan Karyawan (SOJUPEK), rachmawati Soekarno Putri, Wakil Ketua Dewan Perwakilan Daerah (DPD) La Ode Ida, mantan Menteri Pemuda Olahraga Adyhaksa Daut, serta beberapa pemohon individu lainnya mengajukan uji materil terhadap Undang-Undang nomor 7 tahun 2004 Tentang Sumber Daya Air (SDA). Pengujian ini dipicu dengan adanya penyelewengan terhadap pertimbangan Mahkamah Konstitusi (MK) dalam putusan perkara 058.059.060.063/PUU-II/2004 dan perkara 008/PUU-III/2005.

Sidang perdana yang dipimpin Hakim Konstitusi Muhammad Alim, Para Pemohon melalui kuasa hukumnya, Syaihfrul Bakri, mempersoalkan terbitnya Peraturan Pemerintah (PP) nomor 16 Tahun 2005 Tentang Pengembangan Sistem Penyediaan Air Minum, yang memberikan kesempatan kepada koperasi, badan usaha swasta, atau kelompok masyarakat untuk meyelenggarakan Sistem Penyediaan Air Minum (SPAM). Syaihfrul Bakri menyatakan bahwa ketentuan yang diatur oleh PP tersebut telah menyimpang dari penafsiran MK yang tertuang dalam pertimbangan putusan PUU Sumber Daya Air yang telah diputus pada 2005 lalu.

Menurut Syaihfrul Bakri dalam pertimbangan yang diputuskan oleh MK, MK menyatakan "sehingga, apabila UU a quo dalam pelaksanaan ditafsirkan lain dari maksud sebagaimana termuat dalam pertimbangan Mahkamah diatas, maka terhadap UU a quo tidak tertutup untuk diajukan pengujian kembali" karena pasal 40 UU SDA menegaskan bahwa pengembangan Sistem Penyediaan Air Minum (SPAM) adalah tanggung jawab pemerintah pusat atau pemerintah daerah, sehingga penyelenggaraan SPAM adalah Badan Usaha Milik Negara (BUMN) atau Badan Usaha Milik Daerah (BUMD).

Pemerintah yang diwakili oleh Sekretaris Jenderal Kementerian Pekerjaan Umum (KemenPU) Agus Widjinarko menerangkan, persoalan yang dikemukakan oleh Para Pemohon dalam permohonannya merupakan masalah implementasi norma dan bukan 
masalah konstutisionalits norma. Penyediaan air minum dan air baku dalam SPAM diperlukan pendanaan yang sangat besar yang sumbernya diambil dari APBN, APBD, Pusat Investasi Pemerintah, PDAM, CSR Perbankan, Swadaya Masyarakat, serta kerja sama pemerintah dan swasta. Pemerintah dalam hal melindungi masyarakat mengatur beberapa ketentuan yang diatur dalam Peraturan Pemerintah dan Peraturan Menteri Dalam Negeri untuk mengatur tariff. Masyarakat sebagai konsumen melalui forum pelanggan dilibatkan dalam menentukan tarif air serta menyesuaikan dengan kemampuan kelompok masyarakat atau dengan asas proporsionalitas.

Setelah melalui serangkaian sidang, MK membatalakan keberlakuan secara keseluruhan Undang-Undang Nomor 7 Tahun 2004 tentang Sumber Daya Air (SDA) karena tidak memenuhi enam prinsip dasar pembatasan pengelolaan sumber daya air. MK Mengabulkan permohonan Pemohon I, Pemohon II, Pemohon IV, Pemohon V, Pemohon VI, Pemohon VII, Pemohon VIII, Pemohon IX, Pemohon X, dan Pemohon XI untuk seluruhnya. Undang-Undang Nomor 7 Tahun 2004 tentang Sumber Daya Air bertentangan dengan UUD 1945. Dalam pertimbangan tersebut MK menyatakan bahwa sumber daya air sebagai bagian dari hak asasi, sumber daya yang terdapat pada air juga diperlukan manusia untuk memenuhi kebutuhan lainnya, seperti untuk pengairan pertanian, pembangkit tenaga listrik, dan untuk keperluan industri, yang mempunyai andil penting bagi kemajuan kehidupan manusia dan menjadi faktor penting pula bagi manusia untuk dapat hidup layak.

Persyaratan konstitusionalitas UU SDA tersebut adalah bahwa UU SDA dalam pelaksanaannya harus menjamin terwujudnya amanat konstitusi tentang hak penguasaan negara atas air. Hak penguasaan negara atas air itu dapat dikatakan ada bilamana negara, yang oleh UUD 1945 diberi mandat untuk membuat kebijakan (beleid), masih memegang kendali dalam melaksanakan tindakan pengurusan (bestuursdaad), tindakan pengaturan (regelendaad), tindakan pengelolaan (beheersdaad), dan tindakan pengawasan (toezichthoudensdaad). Dalam pokok permohonannya, para pemohon menjelaskan ada penyelewengan terhadap pertimbangan MK dalam putusan perkara 58-59-60-63/PUU-II/2004 dan perkara 8/PUU-III/2005, perihal pengujian UU Nomor 7 Tahun 2004 tentang Sumber Daya Air. Penyelewengan norma tersebut berdampak dalam pelaksanaannya yang cenderung membuka peluang privatisasi dan komersialisasi yang merugikan masyarakat. Sejak terbitnya PP No. 16/2005 tentang Pengembangan Sistem Penyediaan Air Minum (PP SPAM), semakin menegaskan kuatnya peran swasta dalam pengelolaan air. Padahal, UU SDA menegaskan, pengembangan SPAM merupakan tanggung jawab pemerintah pusat/pemerintah daerah, sehingga penyelenggaranya adalah Badan Usaha Milik Negara (BUMN)/Badan Usaha Milik Daerah (BUMD). Hak Guna Pakai Air menurut UU SDA hanya dinikmati oleh pengelola yang mengambil dari sumber air, bukan para konsumen yang menikmati air siap pakai yang sudah didistribusikan

Akibat dari putusan MK tersebut, Pemerintah akan merenegoisiasi kontrak kerja sama pemanfaatan sumber air bersih. Hal itu untuk mendukung pemerintahan daerah menyediakan air bersih bagi masyarakat. Renegoisasi ini menungkinakan pemutusan kerja sama dengan pihak swasta yang selama ini menguasai sumber air. Selain menyesuaikan dengan Undang-Undang Nomor 11 Tahun 1974 tentang Pengairan yang kembali diberlakukan, regenoisasi untuk membatasi pengusahaan air oleh swasta demi mengembalikan penguasaan pemerintah atas air sesuai putusan Mahkamah Konstitusi. Dalam mengantisipasi potensi kekisruhan atau kekhawatiran pelaku usaha ihwal putusan Mahkamah Konstitusi yang membatalkan Undang-Undang Nomor 7 Tahun 
2004 tentang Pengaturan Sumber Daya Alam, maka Kementerian Pekerjaan Umum dan Perumahan Rakyat segera menerbitkan Peraturan Pemerintah (PP). Keberadaan PP penyesuaian dinilai krusial, lantaran Undang-Undang Nomor 11 Tahun 1974 tentang Pengairan yang otomatis kembali berlaku tidak sesuai dengan kondisi terkini, karena aturannya kurang spesifik dan memiliki instrument yang sedikit.

Maka sangat menarik sekali untuk meneliti pemenuhan Hak Sumber Daya Air di Kota Padang, terutama pasca MK membatalakan keberlakuan secara keseluruhan Undang-Undang Nomor 7 Tahun 2004 tentang Sumber Daya Air (SDA) dan mengembalikan pengaturan tentang SDA ini kembali ke undang-undang sebelumnya, yaitu Undang-Undang Nomor 11 Tahun 1974 tentang Pengairan, yang dirasa kurang efisen dengan keadaan kehidupan sekarang ini.

\section{B. Metodologi Peneltian}

Penelitian merupakan terjemahan dari bahasa Inggris yaitu research, yang berasal dari kata re (kembali) dan to search (mencari). Dengan demikian secara logawiyah berarti "mencari kembali". Penelitian merupakan suatu sarana pokok dalam pengembangan ilmu pengetahuan maupun teknologi. Hal ini disebabkan, oleh karena penelitian bertujuan untuk mengungkapkan kebenaran secara sistematis, metodologis, dan konsisten. Melalui proses penelitian tersebut diadakan analisa dan konstruksi terhadap data yang telah dikumpulkan dan diolah (Soerjono Soekanto, Sri Mamudji, 2011). Penelitian ini berjenis penelitian yang bersifat deskriptif analitis (Arikunto, Suharsimi, 2002), yaitu suatu bentuk penelitian yang bertujuan untuk menggambarkan peraturan perundang-undangan yang berlaku, dikaitkan dengan dengan teori-teori hukum dan praktek pelaksanaan hukum positif, yang nantinya akan disangkutkan dengan permasalahan yang diteliti dalam karya ilmiah ini. Penelitan deskriptif sendiri merupakan suatu penelitian yang bermaksud memberi gambaran suatu gejala sosial tertentu, suda ada informasi mengenai gejala sosial seperti yang dimaksud dalam permasalahan penelitian, namun merasa belum memadai. Penelitian ini biasanya menjawab apa penjelasan yang lebih terperinci mengenai gejala sosial seperti yang dimaksudkan dalam suatu penelitian yang bersangkutan (Marnasse Malo dan Sri Trisnongtias, 1997).

\section{Hasil dan Pembahasan}

Salah satu latar belakang pengakuan hak asasi manusia atas air adalah kelangkaan air (water scarcity). Menurut data awal dekade ini, sekitar tahun 2000, perhitungan air di dunia dapat diperkirakan menjadi 2,5\% air tawar (freshwater) dan 97,5\% merupakan air laut (saltwater). Dari 2,5\% air tawar tersebut, 87\% nya merupakan es/glaciers permanen. Sisanya sekitar 13\% merupakan air darat dan air danau/sungai yang terdapat risiko tercemar polusi. Perkiraan lain yang timbul berdasarkan konfigurasi distribusi air tersebut, dan juga dikarenakan perubahan iklim global, maka kelangkaan air (water scarcity) akan meningkat sebesar $20 \%$ dalam 25 tahun ke depan. Di sisi lain, penduduk terus bertambah dan kebutuhan lahan pertanian untuk memberi makan penduduk bumi juga semakin bertambah pula. Data tersebut didukung oleh banyak hasil studi. Salah satunya adalah suatu riset yang dibuat oleh International Water Management Institute (IWMI), sebuah pusat penelitian di bawah badan bernama Consultative Group on International Agricultural Research (CGIAR). Dari hasil penelitiannya, IWMI mendapati bahwa 
sepertiga penduduk dunia diperkirakan akan mengalami kelangkaan air yang parah dalam jangka sampai dengan tahun 2025 (David Seckler, 1998).

Kelangkaan air itulah yang mendorong badan-badan keuangan internasional dan negara-negara pemodal itu membawa masuk air ke dalam kerangka pikir ekonomi kapitalisme, yakni bahwa semakin langka suatu benda, semakin tinggi nilai ekonominya. Seolah-olah mereka -Bank Dunia dan negaranegara pemodal- menafikan bahwa air memiliki sifat sebagai barang/benda publik. World Health Organization (WHO) telah menegaskan bahwa harga air harus terjangkau. Harga air tidak boleh lebih dari 3-5\% pengeluaran seorang warga. Namun di Cochabamba, Bolivia seorang warga harus mengeluarkan sekurangnya $25 \%$ untuk membayar kebutuhan airnya akibat terjadinya kelangkaan sumber air. Sebagai upaya pemecahan masalah tersebut, organisasi internasional mengambil langkah menetapkan bahwa air tidak lagi sebagai barang ekonomi tapi air harus dianggap sebagai hak sosial dan budaya. Oleh karena itu, ada beberapa pendekatan yang dapat dilakukan, yaitu 1) menganggap hak atas air sebagai sub ordinat dari hak asasi manusia yang diatur dalam perjanjian internasional tentang hak asasi manusia (misalnya Bill of Human Rights), 2) menganggap hak atas air sebagai sub ordinat dari hak lainnya, misalnya hak sosial dan budaya International Covenant on Economic, Social and Cultural Rights (ICESCR), atau 3) menganggap air sebagai hak yang berdiri sendiri, sehingga negara wajib untuk menjamin pemenuhannya.

Tahun 2002, the ECOSOC Committee on Economic, Social and Cultural Rights menyampaikan sebuah pernyataan bahwa "The Committee has been confronted continually with widespread denial of the right to water (...)." Lembaga yang berada dalam naungan PBB tersebut kemudian menerbitkan "General Comments on the Right to Water" (General Comments No.15/GC-15) yang antara lain memuat penyataan. The human right to water entitles everyone to sufficient, safe, acceptable, physically accessible and affordable water for personal and domestic uses. An adequate amount of safe water is necessary to prevent death from dehydration, reduce the risk of water-related disease and provide for consumption, cooking, personal and domestic hygienic requirements.

Inilah kesempatan pertama hak atas air secara eksplisit disebut sebagai hak asasi manusia dalam sebuah dokumen resmi. GC-15 ini bukanlah sebuah perjanjian, tapi merupakan hasil interpretasi Committee on Economic, Social and Cultural Rights (CESCR) atas Kovenan Internasional tentang Hak-hak Ekonomi Sosial dan Budaya (the International Covenant on Economic, Social and Cultural Rights - ICESCR). ICESCR merupakan produk hukum yang mengikat, tetapi GC-15 tidak demikian, walaupun pada gilirannya CESCR/ECOSOC dapat menerapkan langkah-langkah yang dapat 'memaksa' negara-negara untuk melaksanakan Kovenan itu berdasarkan interpretasi ECOSOC. Hal ini dimungkinkan karena GC-15 didasarkan atas ketentuan-ketentuan dalam ICESCR dan ketentuan umum DUHAM seperti hak untuk hidup dan hak atas kesehatan (Williams, Mellina, 2007).

Terkait dengan peran negara sebagaimana "dipaksa" oleh GC-15, pada dasarnya, negara memiliki 3 kewajiban dalam pemenuhan hak asasi, yaitu 1)kewajiban untuk menghormati hak asasi, 2) melakukan pencegahan terhadap pelanggaran dari pihak ketiga dan 3) kewajiban untuk menjamin pemenuhan hak- hak asasi manusia tersebut. 


\section{Penutup}

Belakangan timbul pendapat bahwa bila negara tidak mampu menjamin pemenuhan hak-hak asasi manusia atas air, maka penyediaan air dilakukan oleh pihak ketiga. Negara harus melakukan pengaturan terhadap kepatutan penguasaan terhadap sumber air, keterjangkauan harga, jaminan terhadap kesehatan air. Demi terwujudnya hal-hal tersebut, suatu sistem pengaturan harus dibuat. Dapat pula dibentuk suatu badan pengawas independen, partisipasi publik, dan sanksi terhadap pelanggaran. Pada intinya, setiap regulasi yang dikeluarkan pemerintah daerah terkait pemanfaatan air justru menjadikan air sebagai "Economic goods". Komersialisasi dan privatisasi pelayanan air bukanlah menjadi suatu barang yang haram sepanjang hal tersebut dapat meningkatkan pelayanan air bersih sehingga meningkat pula akses masyarakat terhadap air. Seharusnya pemerintah daerah dapat memahami bahwa komersialisasi sumber daya air dengan menetapkan tarif air minum yang melebihi batas kemampuan dan kewajaran masyarakat justru mengakibatkan berkurangnya akses masyarakat terhadap sumber daya air, khususnya air bersih dan air minum. Masyarakat miskin dan marginal menjadi kelompok masyarakat yang paling rentan terhadap gagalnya pemenuhan hak atas air oleh Negara. Untuk melihat sejauh mana pemenuhan hak atas air oleh negara selain dari sudut pandang otoritas eksekutif, maka perlu dilihat putusan-putusan pengadilan yang dapat mencerminkan pemenuhan hak atas air terutama pasca dihapusnya Undang Undang Nomor 7 Tahun 2004 Tentang Sumber Daya Air Oleh Mahkamah Konstitusional dan kembali kepada Undang-Undang Nomor 11 Tahun 1974 tentang Pengairan.

\section{Daftar Pustaka}

Ali, Zainuddin, 2010, Metode Penelitian Hukum, Cetakan 2, Jakarta: Sinar Grafika.

Arikunto, Suharsimi, 1992, Prosedur Penelitian, Cetakan 8, Jakarta:PT. Rineka Cipta.

Arinanto, Satya, 2008 Hak Asasi Manusia dalam Transisi Politik Di Indonesia, Depok: Pusat Studi Hukum Tata Negara FHUI.

Asshiddiqie, Jimly, 2006, Pengantar Ilmu Hukum Tata Negara, Jilid II, Jakarta:Konstitusi Press.

Asshiddiqie, Jimly, Cita Negara Hukum Indonesia Kontemporer, orasi ilmiah pada Wisuda Sarjana Hukum Fakultas Hukum Universitas Sriwijaya Palembang.

Chal.id, Hamid, 2009, Hak-Hak Asasi Manusia Atas Air: Studi Tentang Hukum Air di Belanda, India dan Indonesia, Disertasi Doktor Ilmu Hukum FHUI, Jakarta: Program Pasca Sarjana Strata 3.

Kementerian Pekerjaan Umum Republik Indonesia, 2013, Buku Informasi Statistika, Kementerian Pekerjaan Umum Republik Indonesia, Jakarta.

Mardalis, 2010, Metode Penelitian Suatu Pendekatan Proposal, Cetakan 15, Jakarta: Bumi Aksara.

Marzuki , Peter Mahmud, 2009, Penelitian Hukum, Jakarta: Kencana Press.

Muhammad, Abdulkadir, 2004, Hukum dan Penelitian Hukum, Cetakan I, Jakarta: PT. Citra Aditya Bakti.

Rosemary Lyster, "The Current Status of Water Law in New South Wales." Makalah dalam seminar tentang Water Law Reform in New South Wales, the Faculty of Law, the University of Sydney.

Soekanto , Soerjono dan Sri Mamudji, 2011, Penelitian Hukum Normatif, Jakarta: Rajawali Pers. 
UN ECOSOC, Committee on Economic, Social \& Cultural Rights, General Comments No. 15: The Rights to Water.

WHO, 2010, The Global Water Supply and Sanitation Assessment 2000, Geneva.

Williams, Mellina, 2007,"Privatization and The Human Right to Water: Chal.lenges for The New Century,” 28 Michigan Journal of International Law 469. 